\title{
A new species of Janirella Bonnier, 1896 (Isopoda: Asellota: Janirel- lidae) from western Japan Trench
}

Mizuki Ohta, Shigeaki Kojima, Michitaka Shimomura

\begin{abstract}
A deep-sea isopod, Janirella (Janirella) longicauda sp. nov. (Asellota: Janirellidae), was found off the coast of Iwate Prefecture, west of the Japan Trench, at a depth of 3,370-3,547 m by trawling. Janirella longicauda sp. nov. can be distinguished from other species of Janirella Bonnier, 1896 by their long posterior pleotelson, the size differences between the posterior and anterior lateral processes in the pleotelson, the long and tapered rostrum and lateral processes in the pereonites, and the absence of dorsal spines on the pereonites and pleotelson. As a result of the description of this species, the number of species of Janirella (Janirella) known from NW Pacific becomes 12 species.
\end{abstract}

LSID urn:lsid:zoobank.org:pub:10AEA13B-0E99-4411-B667-AC24A9AF6C7F

Key words: Janirella longicauda sp. nov., Janirellidae, deep-sea asellote isopods, Japan Trench

\section{Introduction}

Janirellidae Menzies, 1956 is a deep-sea isopod family in the suborder Asellota Latreille, 1802, superfamily Janiroidea Sars, 1897, comprising three genera (Janirella Bonnier, 1896, Dactylostylis Richardson, 1911 and Triaina Just, 2009). Excluding Dactylostylis serrate (Kensley \& Heard, 1985) and Triaina makidonte Just, 2009, all species belonging to this family are found at depths greater than $500 \mathrm{~m}$. About a half of them are found only in the abyssal (depths between 3,500 to $6,500 \mathrm{~m}$ ) and hadal (depths below 6,500 m) zones (Just, 2009).

Janirella Bonnier, 1896 is the type genus of Janirellidae, and it is the most speciose genus in the family. The genus contains two subgenera, Janirella and Parjanirella Birstein, 1971. Janirella nanseni Bonnier, 1896, the type species of the genus, was described based on a specimen collected at a depth of $950 \mathrm{~m}$ of the Bay of Biscay, during the expedition of the re- search vessel "Challenger". So far, the species of the genus were described from the North and South East Atlantic Ocean, the West Mediterranean Sea, the Puerto Rico Trench, and the North and North Western Pacific Ocean. Janirella was distinguished from the other genera mainly by the combination of the following features; the head has a true rostrum which is simple or complex; the body is fusiform and has lateral spines in general; the coxal plates of pereopods are visible from dorsal side of the body; the protopod of the uropods are uniramous (Menzies, 1962; Just, 2009).

In the North Western Pacific Ocean (NW Pacific), 16 out of 32 species in the genus Janirella are occurring. 11 out of 16 species belong to subgenus Janirella: these include Janirella aculeata Gamô, 1983; J. bicornis Gamô, 1982; J. extenuata Birstein, 1971; J. fusiformis Birstein, 1963; J. hirsuta Birstein, 1963; J. macrura Birstein, 1963; J. ornata Birstein, 1963; J. polychaeta Birstein, 1963; J. rotundifrons Gamô, 1982; J. spinosa Birstein, 
1963; J. tuberculata Birstein, 1963. Remaining 5 species belong to the subgenus Parjanirella (Just, 2009). All Janirella species treated below belong to Janirella (Janirella).

Most of the Janirella species initially described from the NW Pacific Ocean were collected from the Kuril-Kamchatka Trench and the Japan Trench during series of expeditions on the RV "Vityaz", and were reported and described by Birstein $(1963 ; 1971)$. After that, Gamô $(1982 ; 1983)$ examined the specimens collected from the Japan Trench and Sagami Bay during a cruise of the RV "Hakuho-maru", and described three species, J. aculeata, J. bicornis, and J. rotundifrons. However, these species were described based on incomplete specimens, such as juveniles or specimens that were damaged or some parts were missing.

In this paper, we describe a new species of Janirella based on specimens collected from a depth range of 3,370-3,547 $\mathrm{m}$ off the coast of Otsuchi, Iwate Prefecture.

\section{Materials and Methods}

The holotype and paratypes of Janirella longicauda sp. nov. were collected with a $3 \mathrm{~m}$ beam trawl at depths between 3,370 and 3,547 m, off the coast of Otsuchi, Iwate Prefecture, Honshu Island, Japan, during the KS-17-6 expedition on the RV "Shinsei-maru", at station "KANO6" (Fig. 1). Specimens were fixed in $99 \%$ ethanol on board. To observe and study the specimens in the Institute, we used a dissecting microscope (StemiDV4, Carl Zeiss Co., Ltd., Tokyo, Japan) and a compound microscope (Optiphot, Nikon, Tokyo, Japan). Type materials were deposited in the National Museum of Nature and Science, Tokyo. The terminology used for the description was compliant to Just (2009).

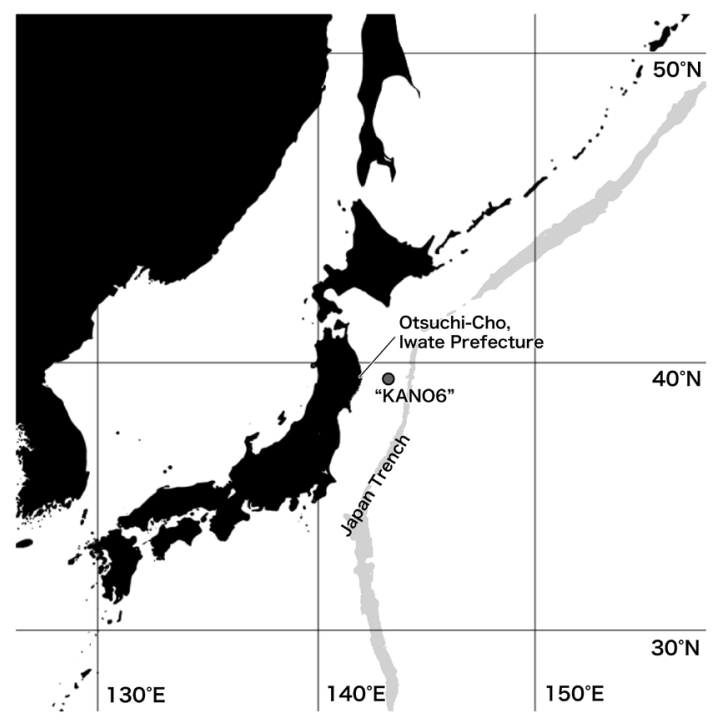

Fig. 1. Chart of the NW Pacific around Japan, showing the location of the Station "KANO6" of the cruise KS-17-6 of the RV "Shinsei-maru", created by processing the GSI map (Geospatial Information Authority of Japan).

\section{Taxonomic Account}

Family Janirellidae Menzies, 1956 Genus Janirella Bonnier, 1896

Subgenus Janirella Bonnier, 1896 Janirella longicauda sp. nov.

LSID urn:lsid:zoobank.org:act:7926FB94CA58-4507-8826-66A3998D160D

(Figs. 2-4)

\section{Material examined}

Type material. Holotype: male, $9.0 \mathrm{~mm}$ (tip of rostrum to apex of pleotelson), NSMT-Cr 27492, western Japan Trench, off Otsuchi, Iwate, Honshu Island, Japan, 39 $25.34^{\prime}-$ $26.02^{\prime} \mathrm{N}, 143^{\circ} 45.14^{\prime}-42.19^{\prime} \mathrm{E}, 3,370-3,547 \mathrm{~m}$, $3 \mathrm{~m}$ beam trawl, 1 August 2017, RV "Shinseimaru", cruise KS-17-6, station "KANO6". Paratypes: 1 damaged female, NSMT-Cr 27493, $5.5 \mathrm{~mm}$ (anterior margin of pereonite 5 to apex of pleotelson), same collection data as for the holotype. 2 damaged males, $6.4 \mathrm{~mm}$ (anterior margin of pereonite 5 to apex of pleotelson), NSMT-Cr 27494 and $5.6 \mathrm{~mm}$ (anterior 


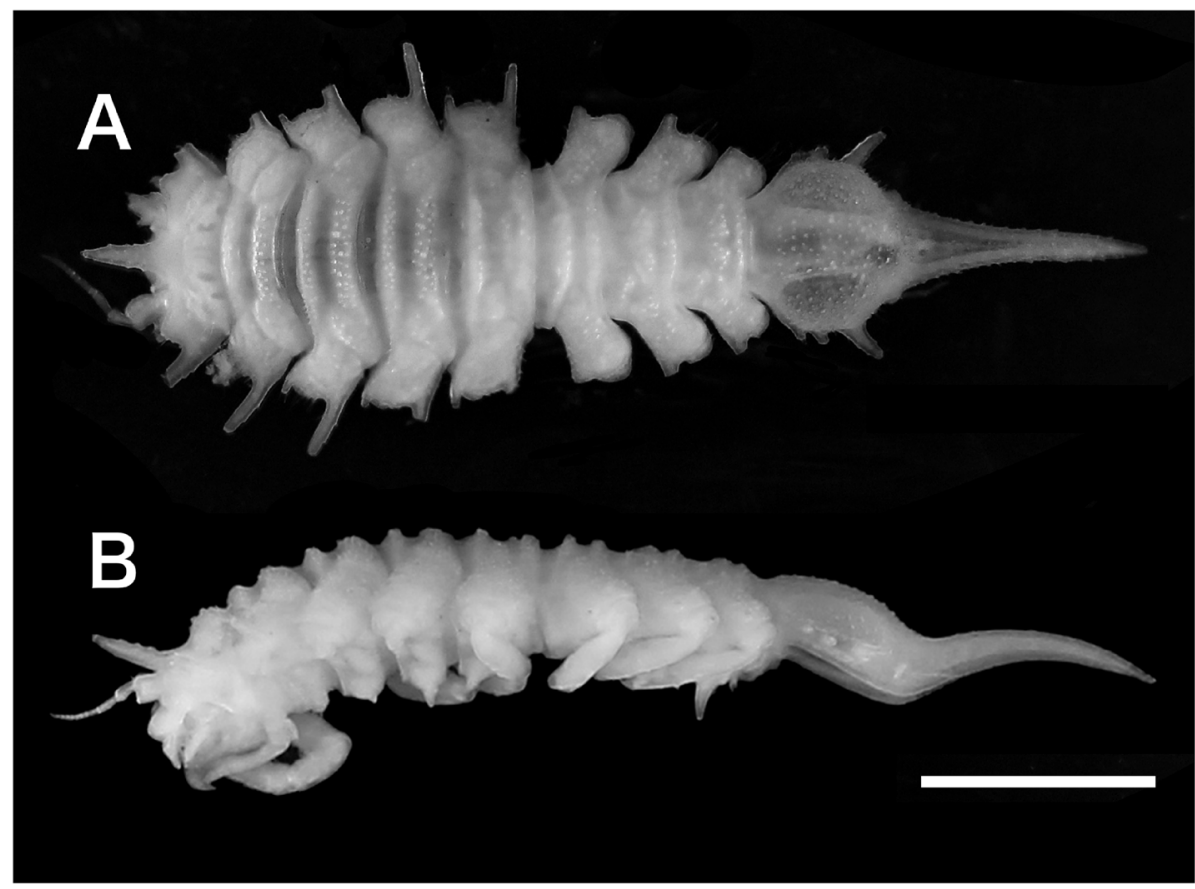

Fig. 2. Janirella longicauda sp. nov., holotype male $(9.0 \mathrm{~mm})$ NSMT-Cr 27492. A, dorsal view; B, lateral view. All pleopods removed for morphological examinations. Scale bar $=2 \mathrm{~mm}$.

margin of pereonite 7 to apex of pleotelson), NSMT-Cr 27495, same collection data as for the holotype.

\section{Diagnosis}

Head, pereonites and pleotelson with numerous granules on dorsum, without dorsal spines. Head with tapered lateral processes; tapered rostrum about 1.5 times longer than head. Pleotelson strongly projecting posteriorly, with 3 pairs of lateral processes; posterior process about 0.6 times as length of pleotelson; posterior pair of lateral processes about 4 times larger than anterior 2 pairs.

\section{Description of holotype male}

Body (Figs. 2, 3A, B) flat, 3 times as long as maximum width (except lateral processes), widest at pereonite 3 . Head, pereonite and pleotelson convex dorsally, with numerous granules, without dorsal spines; lateral processes and rostrum with a few small ledges, with sin- gle spine on tip. Coxal plates (Fig. 3B) dorsally visible on pereonites $2-7$.

Head (Figs. 2, 3A, B) with wide and short anterolareral processes and 1 pair of posterolateral processes as wide as anterolateral ones, dorsally with transverse groove; rostrum tapered elevated as wide as posterolateral processes and about 1.5 times longer than head.

All pereonites (Figs. 2, 3A, B) subequal in length; head to pereonite 3 increasing in width (except lateral processes); pereonites 3 and 4 subequal in width (except lateral processes); pereonites 4 to 7 decreasing in width (except lateral processes). Posterolateral process on pereonite 1 subequal in length and slightly narrower than ones on head; posterolateral processes on pereonites 2-4 with as long and wide as ones on pereonite 1 ; short acute anterolateral processes on pereonites $2-4$ about 0.15 as long as posterolateral ones. Lateral processes of pereonites 5-7 broken. Pereonites dorsally with transverse groove, with granules, bristles grew 

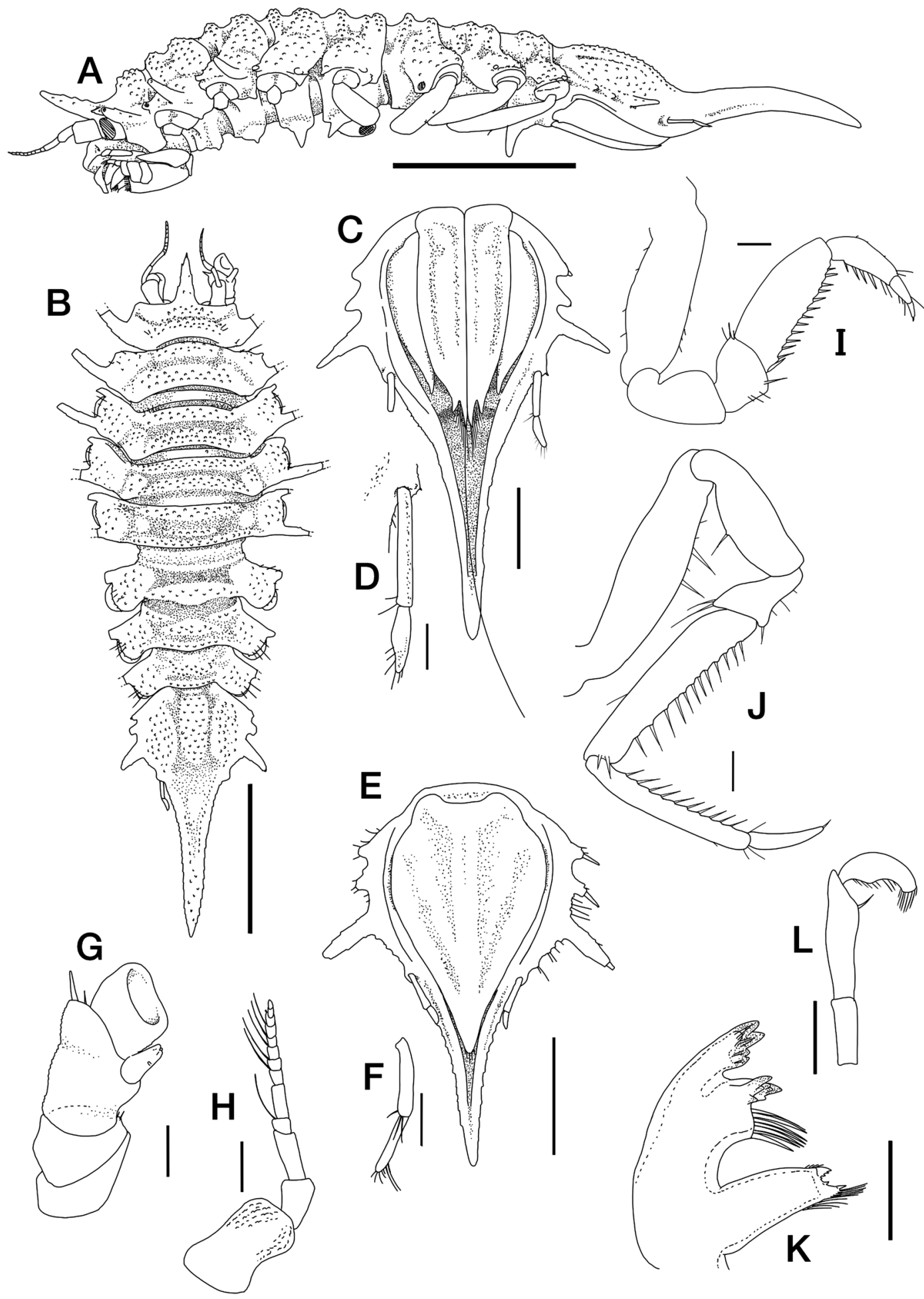

Fig. 3. Janirella longicauda sp. nov., holotype male NSMT-Cr 27492 (except E and F, paratype female NSMT-Cr 27493), A, lateral view; $\mathrm{B}$, dorsal view; $\mathrm{C}$, ventral view of pleotelson with pleopod 1, 2; D, uropod; E, ventral view of pleotelson of paratype female with operculum; F, uropod of paratype female; G, basal segments of right antenna; H, left antennula; I, left pereopod 1; J, left pereopod 2; K, left mandible; L, left mandibular palp. Scale bars $=2 \mathrm{~mm}$ (A and B), $500 \mu \mathrm{m}$ (C and E), $200 \mu \mathrm{m}$ (others). 


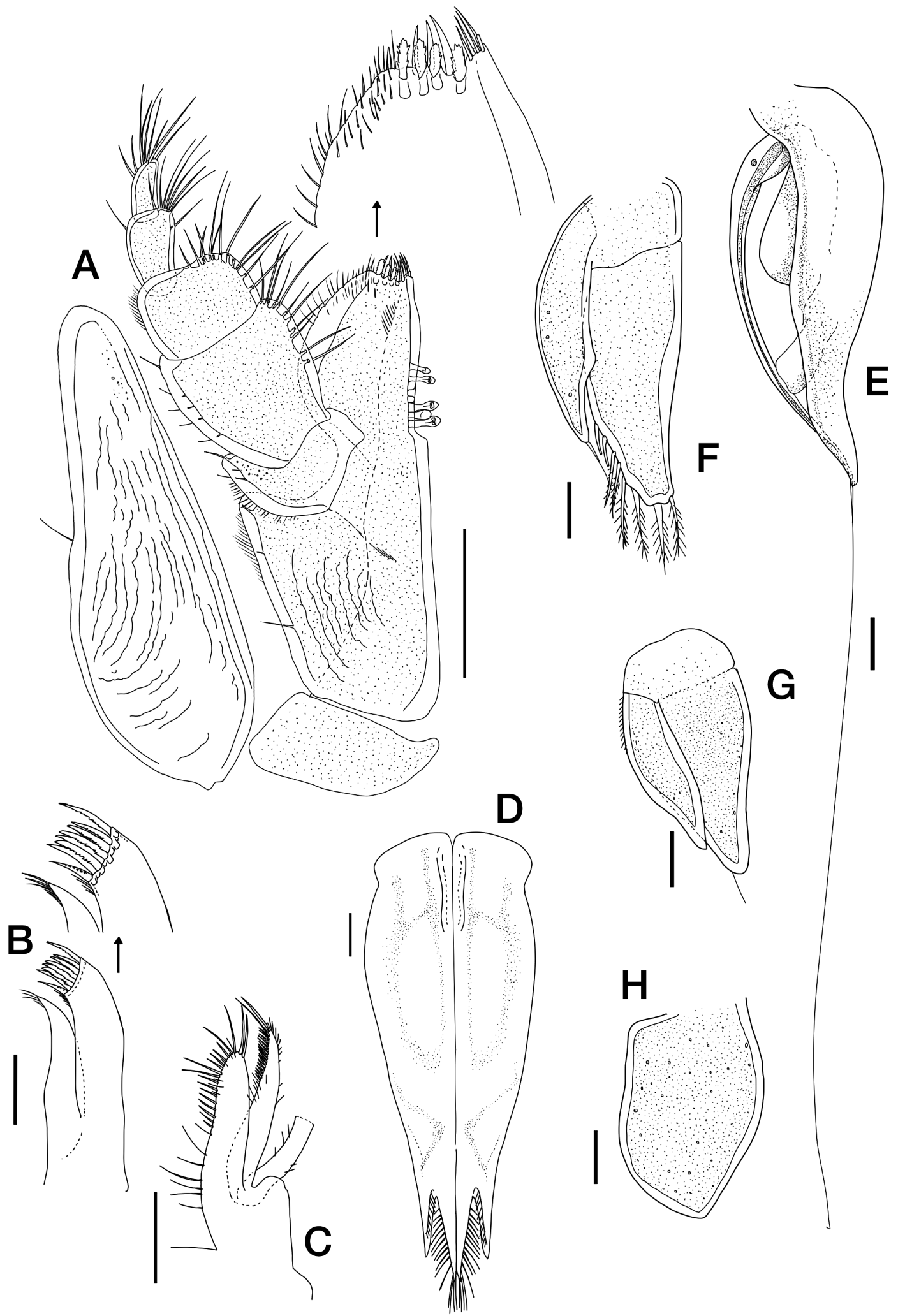

Fig. 4. Janirella longicauda sp. nov., holotype male NSMT-Cr 27492. A, right maxilliped; B, left maxilla 1; C, left maxilla 2; D, pleopod 1; E, left pleopod 2; F-H, right pleopods 3-5. Scale bars $=200 \mu \mathrm{m}$. 
on some granules on towards lateral sides of pereonite. Ventral process of pereonite 1 most small; ventral process of pereonite 2 about twice longer than of pereonite 1; ventral processes of pereonites 3-4 as large as each other and about twice longer than one of pereonite 2; ventral processes of pereonites 5-6 absent; ventral process of pereonite 7 largest and about twice longer than ones of pereonites 3-4.

Pleotelson (Figs. 3A, B, C) with 3 pairs of tapered lateral processes which posterior pairs 4 times larger than anterior 2 pairs, dorsally with 2 transverse grooves, granules on central area and both sides. Pleotelson about 2.3 times longer than maximum width. Posterior process about 0.6 times as length of pleotelson, bent dorsally on midlength.

Antennula (Fig. $3 \mathrm{H}$ ) composed of 13 articles: article 1 most large, cylindrical; article 2 about half longer and half wider than article 1, with 2 long thin setae distally; article 3 as long as article 2, narrower than article 2, with 2 distal short and 1 lateral long thin setae; articles 4 and 5 about 0.2 times longer than article 3, as long as each other, without setae; article 6 about 2.5 times longer than article 5, with 1 short seta distally; articles 7-13 subequal to each other, each with 1 short seta distally.

Antenna (Fig. 3G) peduncle article 5, 6, and flagella broken. Peduncular article 1 triangler, about 0.7 times longer than article 2; article 2 as long as article 3 , cylindrical, with 2 short setae distally; article 3 with 3 -teethed squama with a seta and few simple setae distally; article 4 short, without setae.

Left mandible (Fig. 3K) with setal row of 7 simple setae: incisor 4-toothed; lacinia mobilis 2 times broader than incisor, with 5-teethed process and some simple setae; molar process about 3 times longer than lacinia mobilis, with 3 teeth and setal row of some thin setae distally; most inner distal teeth of molar process serrated, larger than others. Palp (Fig. 3L) 3-articled: article 1 without setae; article 2 about twice longer than article 1 , with a distomesial seta; article 3 about 0.7 times longer than article 2, with 9 distomesial and 8 distal setae. Maxilla 1 (Fig. 4B) outer endite apically with 8 robust serrate setae and laterally with some fine setae; inner endite with 5 thin setae distally. Maxilla 2 (Fig. 4C) outer endite broken; middle endite slender, curved; inner endite broad, shorter than middle lobe, with rounded apex; lateral margins of middle and inner lobes with scattered thin setae; middle endite with 3 simple setae distally; distal half of medial margin with dense row of pointed setae and some thin setae; inner endite with numerous simple setae distomesially and some thin setae medially.

Maxilliped (Fig. 4A): epipod tapering distally, length about 2.8 times longer than maximum width, reaching to base of palp article 4 , covered with cuticular ridge; palp composed of 5 articles; article 1 with 1 lateral seta; article 2 about twice as long as article 1 , as wide as article 1, with 11 lateral setae; article 3 about 0.7 times longer than article 2, with 12 mesial setae; article 4 about 0.8 times longer and narrower than article 3 , with 7 mesial, 1 medial and 1 distolateral simple setae; article 5 narrowest, about 0.8 times shorter than article 4 , with 9 simple setae distally; endite about 1.3 times broader than article 2, distally with row of 4 broad fan-shaped setae and some simple setae, and with some thin setae and 5 coupling hooks on medial margin.

Pereopod 1 (Fig. 3I) shorter than pereopod 2: basis longest article, with some lateral and ventral thin setae; ischium about half longer than basis, trapezoidal; merus about half longer than ischium, trapezoidal, ventrodistally with 1 long and strong and some thin setae, dorsodistally with 3 simple setae; carpus about 3 times longer than merus, ventrally with row of 13 robust setae; propodus about half length of carpus, ventrally with 4 robust and 2 thin setae, and with some lateral and distal simple setae; dactylus about 0.5 times longer than propodus, laterally with 1 simple seta; dorsal claw about 0.4 times as long as dactylus. 
Pereopod 2 (Fig. 3J) long and slender: basis longest article, with some simple lateral setae; ischium about half longer than basis, laterally with 1 simple seta; merus about half longer than ischium, trapezoidal, with some thin ventral, 1 strong ventrodistal and 2 simple dorsodistal setae; carpus about 3 times longer than merus, ventrally with row of 12 robust setae, and with 1 lateral and 2 distal simple setae; propodus about 0.9 times longer than carpus, ventrally with row of 10 robust setae, and with 1 lateral and 3 distal simple setae; dactylus about 0.4 times longer than propodus, with short main claw.

Merus to dactylus of pereopods 3-7 lost. Basis of pereopods 3-7 subequal to length each other, subequal to length of basis of pereopod 2 .

Pleopod 1 (Fig. 4D) about half length of pleotelson, 4 times as long as width, apex bifurcated and pointed, inner bifurcation with row of about 15 thin setae laterally, outer bifurcation with row of about 10 thin setae. Pleopod 2 (Fig. 4E): protopod 0.7 times longer than pleopod 1; article 1 of endopod slightly shorter than protopod; article 2 (stylet) of endopod very long, 1.8 times longer than protopod; exopod about 0.2 times longer than protopod. Pleopod 3 (Fig. 4F): endopod with 8 plumose setae distolaterally, most distal setae about 0.3 times longer than endopod; exopod about 0.8 times longer than endopod, width about half width of endopod, with 1 thin seta distally. Pleopod 4 (Fig. 4G): endopod triangular, with 1 thin seta; exopod about 0.8 times longer than endopod, width about half width of endopod. Pleopod 5 (Fig. 4H) pentagonal-shaped, length about 0.65 times longer than width.

Uropod (Fig. 3D) composed of long protopod and short endopod, each with some thin distal setae; endopod about half length of protopod.

\section{Description of paratype female}

Paratype female damaged, head to pereonite 4 lost.

Pereonites 5-7 like male.
Pleotelson (Fig. 3E) with lateral processes and dorsally grooves like male. Pleotelson about twice longer than maximum width. Posterior process about 0.4 times as length of pleotelson.

Operculum (Fig. 3E) about 1.5 times as long as broad, apex pointed with some thin setae distally.

Uropod (Fig. 3F) more thin and shorter than of male; endopod about 0.8 times longer than protopod.

\section{Etymology}

The species name "longicauda" means "long tail" as it was derived from the Latin words "longus", which means "long", and "cauda", which means "tail". It was appropriately named after the characteristic feature of the species, i.e., long posterior pleotelson.

\section{Remarks}

According to the compilation of the key to species inhabiting the NW Pacific by Birstein (1971), J. longicauda sp. nov. is closely related to $J$. tuberculata based on the following morphological characters: they both have one spine at the apex of the rostrum; the dorsal surface of their bodies are covered with numerous granules, and the apex of the operculum in females is pointed in both species. When comparing both species, the distal process of the pleotelson of $J$. longicauda sp. nov. is significantly longer than that of $J$. tuberculata. In $J$. longicauda sp. nov., the posterior part of the pleotelson, behind the uropod, is longer than the anterior part of the pleotelson; the average ratio of posterior part of the pleotelson in the holotype and in male paratypes is $7: 4$, and the ratio in female paratypes is $3: 2$. In addition, the posterior pair of lateral processes of the pleotelson are approximately 4 times as longer than the anterior two pairs, while in $J$. tuberculata, the posterior pair of lateral processes of the pleotelson are a little longer than the anterior two pairs. Furthermore, specimens of J. longi- 
cauda sp. nov. were collected at a depth range 3,370-3,547 m but $J$. tuberculata were reported at greater depths of 5,350-6,450 $\mathrm{m}$ in previous studies (Birstein, 1963; Gamô, 1983).

Additionally, a closely similar species, $J$. macrura, occurring at a depth of 7,210 $7,230 \mathrm{~m}$ near the Kamchatka peninsula, has rounded operculum apex and lateral processes in its pleotelson that have the same shape as those in J. longicauda sp. nov. (see Birstein, 1963). J. longicauda sp. nov. is distinguishable from $J$. macrura by its peaked operculum and the size differences in the lateral processes in the pleotelson.

Previous studies had reported 6 species of the subgenus Janirella from the areas nearby the collection site of J. longicauda sp. nov. (NW Pacific excluding Sagami Bay): Janirella aculeata $(5,350-5,370 \mathrm{~m}) ; \quad J$. fusiformis (6,156-6,207 m); J. polychaeta $(3,860 \mathrm{~m}) ; \mathrm{J}$. rotundifrons $(5,350-5,370 \mathrm{~m}) ; \quad J$. spinosa $(8,330-8,430 \mathrm{~m})$; J. tuberculata (5,3506,450 m)(Birstein, 1963; Gamô, 1983). The type locality of $J$. longicauda sp. nov. is shallower than the sites where the specimens of these other species were collected probably because sampling on the western slope of the Japan Trench has been performed more closely than before. Therefore more species are expected to be found at various depths of this sea area in future studies.

\section{Acknowledgements}

We are grateful to Y. Kano, T. Takano, F. Bergmeier, H. Yashiki, and the crew members of the RV "Shinsei-maru" for sampling the specimens used in this study. We would like to thank Editage (www.editage.com) for English language editing. We are also greatful to reviewers and editor for useful comments to improve the manuscript.

\section{Literature Cited}

Birstein, J. A., 1963. Deep-sea Isopods of the North-Western Part of the Pacific Ocean. M. Izdatelstvo AN USSR, 213 pp. (In Russian)

Birstein, J. A., 1971. Fauna of the Kurile-Kamchatka Trench. Additions to the fauna of isopods (Crustacea, Isopoda) of the Kurile-Kamchatka Trench. Part II. Asellota 2, vol. 92. In: Trudy Instituta Okeanogiya (eds. Institut geologii geofiziki), Akademiya Nauk SSSR, Moscow, pp. 162-238. (In Russian)

Bonnier, J., 1896. Edriopyhalmes. Résultats scientifiques de la, campagne du "Caudan" dans le Golfe de Gascognes. Annales de l'Université de Lyon, 26: 527-689.

Gamô, S., 1982. Two new deep-sea species of Janirella Bonnier, 1896 (Crustacea Isopoda; Asellota) from Sagami Bay. Science Reports of the Yokohama National University, Section II, Biology and Geology, 29: 1-31.

Gamô, S., 1983. Some species of abyssal asellote isopods (Crustacea) from east of the Japan Trench, with descriptions of Janirella (Janirella) aculeata sp. nov., J. (Parajanirella) sedecimtuberculata sp. nov., and Aryballurops japonica gen. et sp. nov. Science Reports of the Yokohama National University, Section II, Biology and Geology, 30: 1-18.

Just, J., 2009. Triaina, a new genus in the Janirellidae Menzies, 1956 (Crustacea: Isopoda: Asellota), with two new species from southeastern Australia, and a new diagnosis for the family. Zootaxa, 1980(1): 1-15.

Menzies, R. J., 1962. The isopods of abyssal depths in the Atlantic Ocean. In: J. L. Barnard, R. J. Menzies \& M. C. Bacescu, (eds.), Abyssal Crustacea, Vema Research Series 1, Columbia University Press, New York, pp. 83-206.

\section{Addresses}

(MO and SK) Benthos Section, Atmosphere and Ocean Research Institute, The University of Tokyo, 5-1-5 Kashiwa-no-ha, Kashiwa, Chiba 277-8564, Japan 
(MS) Seto Marine Biological Laboratory, Field Science Education and Research Center, Kyoto University, 459 Shirahama, Nishimuro, Wakayama 649-2211, Japan
E-mail address of corresponding author

(MO) ota.mizuki@s.nenv.k.u-tokyo.ac.jp 